\title{
Tüketim Kültürü ve İkna Bağlaminda Reklamda Retorik Figürlerin Kullanimi Üzerine Bir İnceleme
}

\section{Arş. Gör. Deniz Keba Ekinci ${ }^{1 *}$}

Gelis tarihi: 30.09 .2019

Kabul tarihi: 17.10.2019

\section{Atıf bilgisi:}

IBAD Sosyal Bilimler Dergisi

Sayı: Özel Sayı Sayfa: $659-677$

Yıl: 2019

This article was checked by Turnitin. Similarity Index 9\%.

${ }^{1}$ Kocaeli Üniversitesi İletişim Fakültesi, Halkla İlişkiler ve Tanıtım Bölümü, Türkiye, dkeba34@gmail.com, ORCID ID 0000-0003-2723-992X

\footnotetext{
* Sorumlu yazar
}

$\ddot{O Z Z}$

Sanayi devrimiyle ivme kazanan tüketim olgusu zamanla ihtiyaçtan çok görev haline gelmiştir. Eğlenceden kimliklere varıncaya dek her şeyin tüketilebildiği bir ortamda tüketim, bireyin varoluş sebebine dönüşmüştür. Tüketim alışkanlığının devamını sağlayabilmek ve daha fazla tüketime yönlendirmek amacıyla markalar; ürünlerini farklılaştırmak, pazarlamak ve satmak gibi nihai hedeflerini gerçekleștirmek adına tüketicileri ikna etme çabası içine girmișlerdir. Toplumsal bir etkileme biçimi olan, Platon, Aristotales gibi antik Yunan düşünürlerinin alt yapısını oluşturduğu ikna iletișimi günümüze kadar çeșitli yöntemlerle gerçekleștirilmiștir. Bu bağlamda, markalar reklamcılık ve tanıtım faaliyetlerinde "ikna etme sanatı" olarak adlandırılan retorik disiplininden faydalanmışlardır. Bu çalışmada, tüketim kültürünün yaşandığı günümüzde, yazılı basın araçlarından biri olan dergilerde, tüketime özendirme amacıyla yayınlanan basılı reklamlarda kullanılan retoriksel figürler incelenmiştir. Bu çerçevede araştırmanın ana konusunu Türkiye'de 2015 yılında dergilere en fazla reklam veren Loreal Türkiye ve P\&G markalarının reklamlarının retorik yapısının incelenmesi olusturmaktadır. Araștırmanın amacına yönelik olarak, Unilever ve $P \& G$ markalarına ait ürünlerin, Cosmopolitan Türkiye dergisinde Nisan 2015- Nisan 2016 tarihleri arasında yayınlanan toplam 12 sayıda yer alan reklamları Aristotales'in retorik üçlemesi ve figürlerin kullanımı kapsamında dilsel ve görsel retorik betiler çerçevesinde analiz edilmiştir. Sonuç olarak, reklamlarda sözel ve görsel retorik firgürler kullanılarak, yapay gereksinimlerin oluşturulduğu söylenebilir.

Anahtar Kelimeler: Reklam Dili, Retorik, Retorik Figürler, İkna 


\title{
A Research into the Use of Rhetorical Figures in Advertisements within the Context of Consumption Culture and Persuasion
}

\author{
Arş. Gör. Deniz Keba Ekinci ${ }^{1 *}$
}

First received: 30.09 .2019

Accepted: 17.10 .2019

\section{Citation:}

IBAD Journal of Social Sciences

Issue: Special Issue Pages: 659-677

Year: 2019

This article was checked by Turnitin. Similarity Index 9\%.

\author{
${ }^{1}$ Kocaeli Üniversty Faculty of \\ Communication, Public Relations and \\ Publicity, Turkey, dkeba34@gmail.com, \\ ORCID ID 0000-0003-2723-992X
}

\section{* Corresponding Author}

\begin{abstract}
The phenomenon of consumption, which gained acceleration with the industrial revolution, has become a task rather than a need in the course of time. In an environment where all things can be consumed from entertainment to identities; consumption has become the reason of existence for individuals. Trade marks have started trying to persuade consumers for realizing the ultimate goals of differentiating, marketing and selling their products in order to ensure the continuation of consumption habits and to direct more consumption. Being a form of social influence; the communication of persuasion that constituted the infrastructure of ancient Greek philosophers such as Plato and Aristo has been realized in various ways so far. In this context, trade marks have benefited from the rhetorical discipline that is called the "art of persuasion" in their advertising and promotional activities. This study will analyze rhetorical figures that are used in printed advertisements aimed at encouraging consumption in magazines which are among the printed media today, when consumption culture is experienced. In this context, the study mainly aims to examine the rhetorical structure of the advertisements of Loreal Turkey and P \& G trade marks, which had the highest number of advertisements in the Turkish magazines in 2015. For the purposes of the study, Unilever and P \& G brands belonging products have been analyzed in the framework of linguistic and visual rhetoric betide the scope of Cosmopolitan Turkey magazine in April 2015- April 2016 between published a total of 12 points Located ads Aristotle's rhetoric trilogy and the use of figures. As a result, it can be said that artificial requirements are created by using verbal and visual rhetorical firagles in advertisements.
\end{abstract}

Keywords: Advertisement language, Rhetoric, Rhetorical Figures, Persuasion 


\section{GİRIŞ}

Tüketim olgusu sanayi devrimi ile birlikte ivme kazanmış, zamanla da ihtiyaçtan çok görev haline gelmiştir. Bu çerçevede değişen tüketim normları ise bireylere imajların tüketildiği kurgusal bir dünyanın önemli aktörleri rolünü vermiştir. Zamanla insanın kendisine yabancılaşması ve tüketimin pazarlama teknikleriyle kamçılanması sonucu, sürekli alışveriş peşinde koşmayı ve satın almayı mutluluk kabul eden bir kültürün temelleri atılmıştır (Dolu, 1993, s.34). Tüketim olanaklarının çoğaldığı eğlenceden, kimliklere varıncaya dek her şeyin tüketilebildiği böyle bir topluma "tüketim toplumu" denilmektedir. Tüketim toplumu, kendi kuralları doğrultusunda yarattığı kültür ile tüm dünyada genişleyip yayılmacı bir politika benimsemiştir (Aytaç, 2002, s.52). Bireyin varoluş sebebi haline gelen tüketim alışkanlığının devamını sağlayabilmek ve daha fazla tüketime yönlendirmek için yazılı basın boşluğu doldurulamaz bir araç haline gelmiştir.

$\mathrm{Bu}$ anlamda okur kitlesini tüketici kitleye dönüştürmek adına yazılı basının bir parçası olan dergiler de yer alan reklamlar, tüketim normlarını anons ederek okuyucuları tüketime davet etmektedir. Tüketim toplumunun yerleşikleşmesi için genelde sloganvari, etkileyici ve kendi anlam dünyasına bireyi hapseder düşünceler üretilir. Reklam da bunu yaratmak için en iyi dosttur (Yağlı, 2006, s.24). Günümüz tüketim toplumunda reklam aracılığıyla gündelik yaşama küçük dozlar halinde aşılanan tüketim edimi, bireyin kendini koyuverdiği bir ritüele dönüşmüştür ( Akçalı, 2006, s.32).

Reklamlar, tüketicilerin dikkatini çekmek ve tüketime ikna etmek adına, hangi tür mesajın verilmesi reklamın amacına hizmet edecektir düşüncesi ile çeşitli yaratıcı mesaj stratejileri kullanmaktadırlar. Aristotales'e göre bir reklamın ikna etkisinin gücü , mesaj metni yazımına bağlıdır. Bazı araştırmacılar, reklamın dilinin aslında iknanın dili olduğunu düşünmektedir. Reklam metnindeki kelimelerin seçimi, kurgulanışı, mecazi anlam kullanımı ayrıca tekrarlar ve yinelemeler gibi figüratif dil özellikleri olarak adlandırılan edebi sanatların kullanılması reklamın başarısına işaret etmektedir. "Belli bir durumda var olan inandırma yollarını gözlemleme becerisi" olarak tanımlanan retorik, sözün iknayı en etkili biçimde gerçekleştirmesi amacıyla, yargıları coşkularla saptırmayı amaçlamaktadır (2013, s.8). Batı'ya göre reklama iletişimsel değerini veren, gündelik dilden ayrılmasını sağlayan retorik figürlerin kullanılmasıdır. Retorik figürler Sessel, sözdizimsel, anlambilimsel, sözcüksel oyunlar, tekrarlar, yinelemeler ve yer değiştirmeler şeklinde gerçekleşmektedir (Bat1, 2007, s.328). Dolayısıyla, hedef kitleyi ikna etmek söz konusu ise, retorik figürlerin kullanımı, mesajı düz anlatıma göre farklı bir noktaya taşıyarak oldukça etkili olmaktadır (McQuarrie ve Mick, 1999, s.40).

\section{Tüketim Kültürü Kavramı}

Tüketim kavramı, bazı yazarlar tarafindan olumlu anlamlar yüklenmesine karşın bazıları tarafından da olumsuz olarak nitelendirilmiş ve zaman içerisinde farklı anlamlar kazanmıştır. En basit anlamı ile tüketim, bir şeyleri kullanıp bitirmek, yok etmek demektir. İnsanın fizyolojik, biyolojik, sosyal ve kültürel açıdan çok sayıda meşru ya da meşru olmayan ihtiyacı bulunmaktadır ve bu ihtiyaçların giderilmesi için harcanan ve harcanması göze alınan maddi ve manevi değerlerin seferber edilmesi de tüketim olarak tanımlanmaktadır (Torlak, 2000, s.17).

Tüketim kültürü kökenleri bazı çalışmalarda , İngiltere'de orta sınıflar açısından 18. Yüzyıla; işçi sınıfı açısından ise reklamın, büyük mağazaların, tatil gezintilerinin, kitlesel eğlencenin, boş zamanın geliştiği 19. yüzyıla dayandırılırken (Featherstone, 2005, s.185). Lyon ve Baudrillard'a, tüketim kültürünü postmodernizm ile birlikte düşülmesi gerektiğini savunur. Lyon (1994, s.56) tüketimin ve tüketicinin yaşam tarzının hâkim olduğu bu kültürü postmodern olarak tanımlar. Baudrillard (1996), modernden postmoderne geçişi tüketim talebinin, üretimin merkezi haline gelmesi ile ilişkilendirir. Giddens ise, "yüksek modern dönem" olarak tanımladığı bu dönemi, bireylerin reklamların sunduğu yaşam tarzı paketlerinin rehberliğinde kendilerini "özgür tüketici” olarak ifade ettiklerini söylemektedir (Lyon, 1994, s.60) Yazarların farklı tanımlarla işaret ettiği dönem, sanayi ötesi toplum, geç kapitalist dönem, postmodern toplum, postfordist dönem gibi kavramlarla da anlatılmaktadır. Postmodern ya da geç kapitalist toplum olarak ifade edilen 1980 'ler ve $90^{\prime}$ lar da tüketiceye sunulan yaşam tarzının ön plana çıkarıldığı reklamlar görülmektedir.

Davidson'a (1992, s.66) göre yaşam tarzı bir meta haline gelmiştir. Featherstone (1996, s.41) yaşam tarzı kavramını " bir kimsenin bedeni, giysileri, konuşması, boş zamanı kullanma şekli, yiyecek içecek 
tercihleri, ev, otomobil, tatil seçimleri vb. gibi tüketicinin beğeni üslubunun bireysel işaretleri” olarak tanımlamaktadır. William Leiss'in (1983) Kanada'da ki reklamlar üzerine yaptığı bir çalışmada, son elli yıl içerisinde ürün hakkında enformasyon içeren reklamlardan, yaşam tarzı imgelemlerinin ön plana çıkarıldığı reklamlara geçiş olduğunu ortaya koymuştur (Featherstone, 2005, s.144).

Baudrillard'a göre nesne ve hazza yönelikmiş gibi görünen tüketim davranışları aslında tamamıyla başka amaçlara yanıt verir, Arzunun metaforik ya da dolaylı dışavurumu farklılaştırıcı göstergeler üzerinden toplumsal değerler kodunun üretilmesi. Dolayısıyla belirleyici olan, nesneler toplamı üzerinden bireysel çıkar işlevi değil, göstergeler toplamı üzerinden değerlerin doğrudan toplumsal değiş tokuş iletişimi, dağıtım işlevidir. Dolayısıyla Baudrillard yaşadığımız sürecin insanları gösterge, imaj, simülasyon oyunlarıyla kuşatan ve hipergerçeklik olarak adlandırılan sürece itmiş olduğunu ifade eder. Sahip olduğumuz araçlar, fiziksel ihtiyaçlarımızı karşılamaktan ziyade; statümüzü tayin edici, prestijimizi yansitıc1, insanların gözündeki değerimizi tayin edici görevler üstlenmiştir (Baudrillard, 2015, s. 89-91).

Tüketim merkezli günümüz toplumunda, yapay gereksinimler üretilerek, gerçekmiş gibi gösterilmekte ve bu yapay gereksinimler gerçek ihtiyaçlarımızın önüne geçerek sorgusuzca tüketilmektedir (İnceoğlu, 2011, s.165). Marcuse, tüketim toplumunda yapay gereksinimlerin dayatıldığını vurgulayarak, tüketicilerin bu gereksinimleri gerçekmiş gibi algılmaları için ikna edildiklerini savunmuştur. (Marcuse, 2010, s.22).

Tüketim toplumu içinde yaşadığımızı vurgulayan Baudrillard, gelişen iletişim teknolojileri aracıllğıyla önce ihtiyaçların yaratıldığını sonra da bu ihtiyaçları gidermek üzere bireylerde arzunun oluşturulduğunu ve kişilerin arzularını tatmin etmek için de tüketime yönlendirildiğini ifade etmektedir. Günümüzde, tüketimin sürekliliğini sağlayabilmek adına, ürünlere bir takım anlamlar ve imajlar yüklenilerek tüketim canlı tutulabilmekte, ürünlerin satışı ve pazarlanması gerçekleştirilmektedir. Bu tür pazarlama stratejileri ile tüketiciler sadece ürünü satın almamakta, aynı zamanda sunulan imajı, kimliği veya statüyü de satın almaktadırlar. Sonuç olarak ürünlere yüklenen anlam ve imajlar, tüketiciler açısından adeta bir "var olma nedeni”ne dönüşmektedir (Geçer, 2013, s.71).

\subsection{Tüketim Kültürü ve Reklam İlișkisi}

Günümüz finansal kapitalizmi bilişim ve hizmet sektörü, gelişmiş ülkelerde, az gelişmiş ülkelerde ve gelişmekte olan ülkelerde hızlı bir yükselişe geçmiştir. Bugün kapitalizm varlığını bu sektörlerle sürdürmektedir. Hizmet sektörünü ayakta tutan ise, reklam ve medyadır. Reklamın ve onun belirlediği medya içeriklerinin ortak anlatıs1 ise tüketim kültürüdür (Dağtaş, 2009, s.46). Bugünün tüketim toplumlarında medya kanalları, oluşturulan tüketim kültürünün geniş kitlelere aktarılmasında önemli unsurların başında gelmektedir, Tüketim kültürünün yayılmasını sağlayan pek çok yeni oluşum söz konusu olmakla birlikte, medya, tüketim ilişkilerinin en temel yaratıcısı konumundadır (Konyar, 2000, s.25).

Odabaşı (1999, s.27), tüketim kültürünü, pazar dinamiklerinin egemen olduğu, pazar ekonomisinin var olduğu toplumların kültürü olarak tanımlarken, Bauman'a göre tüketim kültürü düşüncesinin gücü, kitlesel pazarlama ve onunla ilişkili reklâmcılığa dayanmaktadır (1999, s. 34). Baudrillard (2015) ise, çağdaş tüketicilerin, kapitalizmde ürünleri değil göstergeleri tükettiğini ifade eder. Reklamlar aracıllğıyla tüketim nesnesi olarak sunulan göstergeler ile tüketimde ihtiyaçların yerini toplumsal değerlerin ve imajların yer aldığı görülmektedir.

\section{2. İkna ve Retorik}

Retoriğin tarihçesine bakıldığında Antik Yunan felsefesinin en önemli isimlerinden olan ayrıca Platon'un da öğrencisi Aritotales'in etkisinin oldukça büyük olduğu görülmektedir. Aristotales klasik retorik anlayışını sistemleştiren, özgün katkı sunan, günümüze kadar devam eden bir retorik anlayışı ortaya koyan ve retorik için önemli isimlerden biridir (Aristoteles, 2013, s.19).

Aristotales'e göre retorik; politik, adli ve epideiktik (törensel gösteri söylevi) olmak üzere üç tür söylevden oluşmaktadır. Politik retorik, gelecek zamanda kurgulanmaktadır, içerisinde cesaret ve umut kırma vardır. Adli retorik ise, Geçmiş zamanı içermekle birlikte temel olarak kötü davranışı incelemektedir. Adalet ve yasalarla ilgili sonuçlara ulaşılmaktadır. Son olarak törensel söylev, övgü ya da eleştiri içerir, erdem ve kusurla ilgilenir (Aristoteles, 2013, s.20-25). Retorik; zaman, söylev ve amaç 
içinde varlığını gösterir. Retoriğin üç türü kendi içinde başka bir üç kavram daha barındırmaktadır. Bu üç kavram retoriğin amaca göre sinıflandırılmasından oluşmaktadır. Retorik, üç amaca da hizmet verdiği düşüncesinden çıkılarak amacın temeli; saptamak, tanıtmak ve kanıtlamak biçiminde de siralanabilmektedir. (Barokas, 2011, s.63-64).

Aristoteles'in "Rhetoric" adlı eserinde "Üç İkna Kanıtı" olarak belirlenen öğretilerde ikna sanatı ele alınmıştır. Önce Atina ve Roma 'da daha sonraları ise, İngiltere, Amerika gibi ülkelerde etkili olan bu ögretiler, günümüzde hala geçerliliğini ve etkisini korumaktadır. Artistik kanıtlar (Artistic Proofs) olarak da isimlendirilen bu kanıtlar; ethos, pathos ve logostur. Ethos, konuşmacının kişisel karakterine bağlı iken, pathos, duygusal yollar ile dinleyiciyi istenilen ruh haline sokabilmektedir. Logos ise, konuşmacının sözcüklerle kanıtına bağlı olan öğedir (Zıllığlu \&Yüksel, 2005, s. 88).

Kökeni etik kelimesine dayanan Ethos kavramı, ikna edici mesajı gönderen kişinin dinleyiciler tarafindan algilanan zeka, iyi niyet ve karakterini ifade eder (Benjamin, 1997, s.78). İnsanlar karşılaştıkları etkili sunumlarda, konuşmacının fiziğinden, giyiminden, konuşma tarzı ve şeklinden, hareketlerinden etkilenerek, ikna olmaya başlarlar. Bazen de, iknacının, konuşmacının ortaya koyduğu dürüst tavır, mizah gücü, deneyim gibi özellikleri ya da bu konularda geçmişten gelen bir unvanının olması iknayı kolaylaştırabilir. (Sandıkçıoğlu, 2014, s.22). Ethos günümüzde, "inandırıcılık" veya "kaynağın inandırıcılığı" kavramları ile nitelendirilmektedir. İkinci ikna kanıtı olan Pathos, Duygusal öğeleri kullanarak, dinleyicileri etkileyerek ikna etmeyi kapsamaktadır. Pathos da dinleyicilerin tutkuları önemlidir, uygun bir duygusal çizgide tutmak inandırmayı beraberinde getirmektedir (Kast, 2011 ).

Logos ise, mantık ile ilintilidir. Etimolojik olarak İngilizce "Logic" mantık sözcüğünün kökenidir. Aritotales logos'u akı1 yürütmeye dayalı söylem olarak nitelendirmektedir (Sönmez, 2008, s.108). Bazı retorisyemlere göre, felsefi olarak iddianın en önemli boyutu, mantıksal sav ve kuvvetli içerik taşıyan logostur. (Cutbirth, 2004, s.82). Bıçakçı'ya göre ise, Aristoteles bu üç unsur arasından en çok logos üzerinde durmuştur. Herkesin bildiği 'Aristo mantığı' denen düz mantıksal çıkarım formülü ortaya çıkmıştır (2012, s.338).

\subsection{Reklamda Retorik Figürlerin Kullanımı}

Retorik sanat1, 2000 yıldan fazla bir süredir dünya düşünce sistemini şekillendiren olgulardan biridir. Alan araştırmacıları 1990'lardan başlayarak, özellikle tüketici davranışları kapsamında retorik unsurların etkisini düzenli bir şekilde incelemeye başlamışlardır. Günümüzde ise, retoriğin tüketici araştırmaları ve reklamcılık alanlarında incelenen bilimsel geçerliğe sahip bir disiplin olduğu rahatlıkla söylenebilmektedir. (McQuarrie ve Phillips, 2008, s.3-4). Reklam retoriği alanında yapılan çalışmalar kapsamında hedef kitleyi ikna etmek ve etkilemek amacıyla kullanılan bir disiplin olma özelliğini taşımaktadır. Retorik reklam dili, ifadeyi abartılı ve kurnazca anlatmanın bir yolu olarak, mesajı zenginleştirmek adına kullanılmaktadır (Dyer, 2009, s.127).

Retorik figürleri şemalar ve mecazlar olarak iki gruba ayıran McQuarrie ve Mick (1996)'e ait olan sınıflandırma aşağıdaki gibidir.

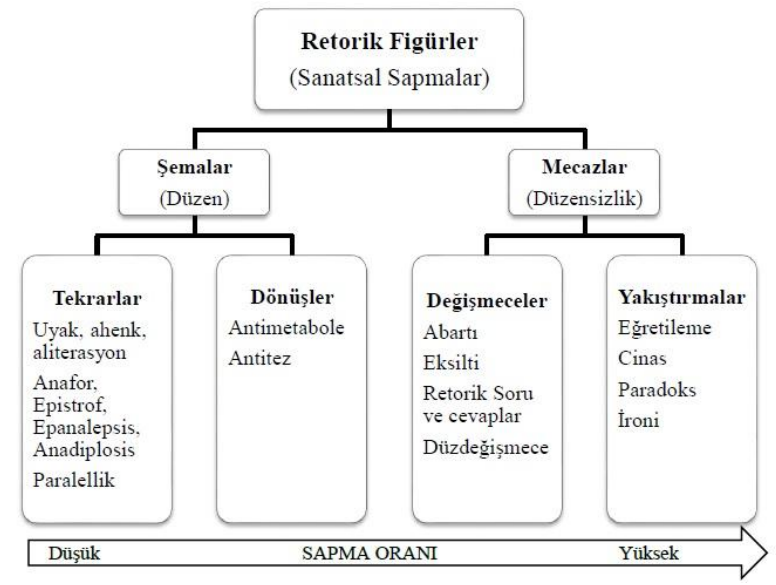

Şekil 2, Retorik Figürler (McQuarrie ve Mick, 1996) 
Retorik figürleri şemalar ve mecazlar şeklinde ikiye ayıran McQuarrie ve Mick'e göre, şemalar; reklam metinlerinin düzenli kurgulanışına bağlıdır. Mecaz figürler, gerçek anlamın dışında, yakıştırmalar veya anlam düzensizlikleri şeklinde gerçekleşmektedir. Şematik figürler ise, belirli bir düzen sonucu ortaya çıkan uyak, ahenk aliterasyon gibi ses ya da hece oyunları olabilir. Eğretileme (metafor) ve cinas gibi gerçek anlamın yanında yan anlamı da güçlü bir şekilde çağrıştıran figürler mecaz kullanıma örnek gösterilebilir (McQuarrie ve Mick, 1996, s.428).

Ses bir dilin en küçük yapı taşıdır. Fonoloji yani ses bilim, dil bilim dallarından biri olup insan dilinin çeşitli birimleri ve öğelerini oluşturan sesleri inceler. Aynı zamanda, ses unsurlarının kaynağı, dil seslerinin nitelikleri sınıflandırılması, seslerdeki değişim ve gelişmeler, vurgu ve tonlama, sesle ilgili söz oyunları gibi konuları ele alır. Reklam dilinin dikkat çekici ve etkili olabilmesi için dil öğelerinin doğru ve yerinde kullanılması gereklidir. Reklam dilinde sıklıkla tercih edilen ses yinelemesi, ritim, uyak gibi öğelerdir (Batı, 2010, s. 171).

Şemalar, tekrarlar ve dönüşlerden oluşmaktadır. Seslerin tekrarı neticesinde ortaya çıkan figürler kafiye (uyak), ahenk ve aliterasyon olarak adlandırılmaktadır. Kafiye, ses akışkanlığının kurallara uygun vezinli biçimidir (Tamaşevski, 1995, s.139). Reklamlarda kafiye (uyak), sesbilimsel bir öğe olarak, söze kazandırılan güzellik ve etkililik sayesinde, reklam iletisinin kolay okunabilmesini ve hatırlanabilmesini amaçlamaktadır. (Batı, 2010, s. 175). Ses yinelemesi olarak nitelendirilen aliterasyon, uyak gibi ses oyunları reklamcılıkta kullanılan önemli retorik araçlardır. Şemalar kategorisinde yer alan anafor, epistrof, epanelepsis ve anadiplosis ise kelime tekrarına dayalı sanatsal uygulamalar olarak bilinmektedir (McQuarrie ve Mick, 1996, s. 430). Dönüşler şeklindeki retorik figürlerden antimetabol, ardışık cümle içindeki sözcüklerin tekrarına dayanmaktadır, Antitez ise, bir cümle içerisinde birbirine zıt kelimelerin kullanımları sonucunda ortaya çıkan sanatsal sapmalardır (Çam, 2015, s.47).

Anlamda bir sapma veya değişme durumlarında ortaya çıkan mecaz figürler değişmeceler ve yakıştırmacalar olmak üzere ikiye ayrılmaktadır. Değişmeceler kategorisinde, Abartı, Eksilti, Retorik Soru, Cevabi Açıklama, ve Düzdeğişmece retorik figürler yer almaktadır. Abartıda anlatılmak istenen, abartılı terimlerle büyütülerek ifade edilir. Olumsuz davranışlar dramatizasyonla birlikte abartılarak verilir. Eksilti, anlam ve biçim olarak doldurulması gereken boşlukların bulunduğu cümlelerde kurgulanan figürlerdir. Metinlerde karşılıklı konuşma esasına dayalı soru sorma şeklindeki retorik figürler retorik soru olarak adlandırılır. Cevabi açıklama, sorulan soruya karşılık açıklama içerecek şekilde ortaya çıkan figürdür. (Özdemir, 1992, s.41). Düzdeğişmece, bir kavramın, ilgili olduğu başka bir kavram ile açıklanmasıdır. Düzdeğişmece içinde bir şeyin anlamını göstermek için, o şeyin kendisi yerine, ona ait bir özelliği gösterilir (Bat1, 2010, s. 115).

Eğretileme, Cinas, Paradoks ve İroni yakıştırmalar kategorisindeki retorik figürlerdir. Türkçe karşılığı Eğretileme olan Metafor, bir kavramı başka bir yoldan ifade etmek anlamına gelmektedir. Reklam dilinde sıklıkla görülen eğretileme de, bir şeyin kendi anlamı dışında türlü yönlerden benzediği bir başka şeyin adıyla anılması söz konusudur (Sperber ve Wilson 1986'dan akatarn, Bat1, 2010, s.111). Anlamları farklı, yazılışları ve söylenişleri aynı kelimelerin birlikte kullanılmasına Cinas denir. Reklamlarda sıklıkla kullanılan Cinas sanatı, reklamın etkisini arttırmak için slogan ve görsellerle birlikte kullanılır (Barokas, 2011, s.61). Paradoks, mesaj akatarımı yapılan metinlerde, çelişkiyi, yanlış ya da imkânsız bir kurgulama ile kullanılan retorik figürlerdir. Anlatmak istenilen mesajla dalga geçmek veya anlatıldığı gibi olmadığını belirtmek, göstermek amacıyla metinle tam ters yönde bir resim veya fotoğrafın kullanılmasına İroni denir (McQuarrie ve Mick, 1999, s.46).

Görsel ve dilsel reklam iletilerinde kullanılan diğer retorik figürler ise yankılama ve kişileştirmedir. Yankılama, ifade edilmek istenen yazılı mesajı pekiştiren ya da farklı bir anlam oluşturacak şekilde resimli/fotoğraflı kullanım sonucunda ortaya çıkan figüratif dil kullanımıdır (Dilçin, 1995, s.412). Kişileştirme ise, insan dışındaki canlı veya cansız varlıklara, insana ait özelliklerin verilmesidir.(Saraç, 2007, s.121). Kişiselleştirme reklamcilıkta oldukça görülen bir yöntemdir. Hem dilsel hem de görsel anlatımda kullanılmaktadır. Görsel olarak ürünleri kahramanlaştırılması ya da onların gizli bir güç haline getirmesidir. Kişileştirmenin en çok televizyon reklamlarındaki temizlik ürünlerinde kullanıldığı görülmektedir (Barokas, 2011, s.62). 
Görsel ve dilsel retorik betilerin kullanımında, özellikle görsel retorik unsurların incelendiği ya da çözümlendiği çalışmalarda çoğunlukla sınıflandırılmış anlam içeren söz sanatlarından görsel eğretilemenin reklam alanında çok kullanıldığı görüşü hâkimdir (McQuarrie ve Mick, 1996, s.427). Johns, görsel eğretilemenin çeşitli türlerini açıklamak için birçok araç kullanıldığını göstermiştir. Onun yapmış olduğu sıralamada yukarıda değinilen abartı, teşbih, eğretileme, düzdeğişmece, kişileştirme gibi araçlar görsel retorikte en sık kullanılan araçlar olarak görülür. Bu araçların yanında Synecdoche; dar anlamlı bir sözcügün anlamını değiştirme biçimi, Ellipsis; anlam bozulmadan sözcüklerin çıkarılması ve Antithesis de kullanılan diğer figürlerdir (Forceville 1998'den aktaran Barokas, 2011, s.64).

Görsel retorik oluşturmada insan unsuruyla sıradan görseller, retoriksel görsel imgelere dönüştürülebilir. Sıradan retorik içermeyen nesneler insanlar tarafından değiştirilerek retorik bir amaca hizmet ettirilebilir (Foss, 2005, s.43). Bir iletişim biçimi olarak göstergebilimsel bir etkinlik olan reklamlarda, görsel retorik unsurların ortaya çıkarılmasında, çözümlenmesinde ve yorumlanmasında göstergebilimsel analiz yöntemlerinden yaralanılmaktadır.

Fiske, göstergeyi kendisinden başka bir şeye gönderme yapan, duyularla kavranabilen fiziksel bir olgu biçiminde tanımlamaktadır (2015, s.69). Göstergenin tek başına bir anlamı yoktur. Gösterge gösteren ve gösterilen kavramlarından oluşur. Uygulamada ise, bir gösterge, nesne ve anlam birlikteliği bulunmaktadır (Williamson, 2001, s.15). Foss'a göre görsel niteliği olan bir nesnenin belirli özellikler içermesi, onun görsel retorik anlam taşıdığını göstermektedir. Bu özellikleri; imge sembolik olmalı, insan unsuru içermeli ve iletişim kurmak amacıyla bir kitleye sunulmalı şeklinde sıralamıştır (2005, s.142-145).

Reklamlarda görsel retoriksel unsurların ortaya çıkarılmasında son zamanlarda Phillips ve McQuarrie'in göstergesel anlama işlemi analizinden yararlanılmaktadır. Phillips ve McQuarrie'in anlam işlemleri; görsel yapının biçim ve içerik açısından konumlandırılmasıdır. Anlam çıkarma ya da anlama işlemi aşağıdaki tabloda görsel retorik tipolojisi olarak adlandırılarak verilmiştir. Görsel yapıyı ortaya koyacak anlam işlemi tablodan da anlaşılacağı gibi sağdan sola üç, yukarıdan aşağıya üç bağlamda incelenir. Yukarıdan aşağıya ürünler yan yana koyma, birleştirme ve yerine koyma ile anlamlandırılır. Sağdan sola ürünlerle bağlantı, benzerlik ve karşılaş̧ırma kavramlarıyla ilişkilendirilir (Barokas, 2011, s.176).

Tablo 1. Phillips ve Mcquarrie'in Görsel Retorik Tipolojisi

\section{Anlama İşlemi}

\begin{tabular}{|c|c|c|c|}
\hline Görsel Yapı & $\begin{array}{l}\text { Bağlantı } \\
\text { A, B ile ilişkilidir }\end{array}$ & $\begin{array}{l}\text { Benzerlik } \\
\text { A, B gibidir }\end{array}$ & $\begin{array}{l}\text { Karşılaştırma } \\
\text { A,B gibi değildir }\end{array}$ \\
\hline $\begin{array}{l}\text { Yan yana koyma } \\
\text { İki imgenin yan yana } \\
\text { konulmasi }\end{array}$ & $\begin{array}{l}\text { İmgelerin bağlantı } \\
\text { kurmak üzere yan yana } \\
\text { konması }\end{array}$ & $\begin{array}{l}\text { İmgelerin benzerlik } \\
\text { ilişkisi kurmak üzere } \\
\text { yan yana konması }\end{array}$ & $\begin{array}{l}\text { İmgelerin karşıtlık } \\
\text { ilişkisi kurmak üzere } \\
\text { yan yana konması }\end{array}$ \\
\hline $\begin{array}{l}\text { Birleştirme } \\
\text { Birleştirilmiş iki imge }\end{array}$ & $\begin{array}{lr}\text { İmgelerin } & \text { bağlantı } \\
\text { kurmak } & \text { üzere } \\
\text { birleştirilmesi } & \end{array}$ & $\begin{array}{lr}\text { İmgelerin } & \text { benzerlik } \\
\text { kurmak } & \text { üzere } \\
\text { birleştirilmesi } & \end{array}$ & $\begin{array}{l}\text { İmgelerin karşı1tlı } \\
\text { ilişkisi kurmak üzere } \\
\text { birleştirilmesi }\end{array}$ \\
\hline $\begin{array}{l}\text { Yerine Koyma } \\
\text { İmge, eksik olan } \\
\text { imgeyi temsil eder }\end{array}$ & $\begin{array}{l}\text { Bağlantı kurmak için } \\
\text { imgenin yerine başka } \\
\text { bir imgenin konulması }\end{array}$ & $\begin{array}{l}\text { Benzerlik kurmak için } \\
\text { imgenin yerine başka } \\
\text { bir imgenin konulması }\end{array}$ & $\begin{array}{l}\text { Karşılaştırmak için bir } \\
\text { imgenin yerine başka } \\
\text { bir imgenin konulması }\end{array}$ \\
\hline
\end{tabular}

Kaynak: Barokas, 2011, s. 176. 


\section{Dergi Reklamlarında Kullanılan Retoriksel Figürlerin Analizi}

\subsection{Araştırmanın Amacı ve Varsayımlar}

Bu çalışmada, okur kitlesini tüketici kitleye dönüştürmek adına yazılı basının bir parçası olan dergilerde yer alan reklamların retoriği anlaşılmaya çalışılmıştır. Bu çerçevede, retorik disiplininin reklam alanına yansımaları tespit edilmek istenmiştir.

Reklam metinleri, varoluş sebebi kapitalizmin ekonomik olarak yeniden üretimi için gerekli olan tüketimi teşvik etme amacı taşıyan bir sektör tarafından üretilen metinlerdir. Günümüzde reklamlar ile gerçek gereksinimlerin dışında yapay gereksinimler dayatılmakta ve bireylerin bu gereksinimleri gerçekmiş gibi görmelerini sağlamak ve tüketimini ikna etmek adına retoriğin gücünden yararlanılmaktadır. Reklamların tüketicileri ikna etme sürecinde, retoriğin gücünü kullanarak, gerçek gereksinimlerin dışında yapay gereksinimler üretmesi araştırmanın problematiğini oluşturmaktadır. Dolayısıyla retorikte geçen söylev kriterleri bu araştırmanın çatısını meydana getirmektedir. İçerik analizi ve göstergebilimsel analiz yöntemi ile sözel ve görsel retoriksel unsurların ortaya çıkarılması amaçlanmıştır.

Reklamların ikna dilinin retorik açıdan incelendiği bu araştırmada iki varsayım kabul edilmiştir. Varsayımların ilki; Reklamlarda retorik figürler kullanılarak yapay gereksinimler oluş̧urulmakta ve bu gereksinim ürünlerinin tüketimi teşvik edilmektedir. Diğer varsayım ise, reklam mesajlarının içeriğinde sözel ve görsel retorik figürlerin kullanıldığıdır.

Araştırma soruları şöyledir: Reklamlarda hedef kitleyi ikna etmek amacıyla kullanılan retorik söylevler hangileridir? Kullanılan retorik türlerinde öne çıkan amaçlar hangileridir? Kullanılan reklam kaynaklarının nitelikleri nelerdir? Reklamlarda kullanılan duygusal çekicilikler hangileridir? Reklamlarda hedef kitleyi ikna etmek adına ne tür kanıtlar kullanılmıştır? Reklam mesajlarının içeriğinde kullanılan sözel retoriksel figürler hangileridir? Reklam mesajlarının içeriğinde kullanılan görsel retoriksel figürler hangileridir?

\subsection{Araştırmanın Kapsamı Metodu}

Araştırmanın evreni kadın ve moda kategorisi dergi reklamları olarak belirlenmiştir. Çalışmada amaçlı örneklem yöntemi kullanılmıştır. Nielsen Türkiye 2015 Reklam Yatırımları Raporu verilerine göre Türkiye'de 2015 y1lında yazılı basında en fazla reklam veren ilk üç markadan ikisi olan Unilever ve P\&G markalarına ait ürünlerin ${ }^{1}$, kategorileri düşünülerek, Kadın ve Moda dergisi kategorisinde en eski ve en fazla tiraja sahip olan dergilerden Cosmopolitan Türkiye dergisi örneklem olarak uygun görülmüştür.

Araştırmanın amacına yönelik olarak, Unilever ve $P \& G$ markalarına ait ürünlerin, Cosmopolitan Türkiye dergisinde Nisan 2015- Nisan 2016 tarihleri arasında yayınlanan toplam 12 sayıda yer alan reklamları dilsel ve görsel retorik betiler kapsamında analiz edilecektir. Dilsel betiler içerik analizi yöntemi ile incelenecektir. İçerik analizi sınırları ve yönü tam olarak belirlenerek kontrol edilebilir hale getirilen belirli ve sistemli bir yorum biçimidir (Bal, 2016, s. 260). Araştırmacı tarafından tanımlanmış araştırma sorusu ve önem arz eden anlam içerikleri üzerinde odaklaşan bir tarama stratejisi söz konusudur (Gökçe, 2006, s. 17).

Bu araştırmada elde edilen veriler Aristoteles'in üç ikna kanıtı; ethos (kaynak niteliği), pathos (duygusal çekicilikler), logos (mantıksal kanıtlar) ve McQuarrie ve Mick (1996)'in çalışmalarından yararlanılarak oluşturulan retorik figürler üzerinden; Görsel retorik betiler ise, Phillips ve McQuarrie'in görsel retorik sinıflandırmasından yararlanılarak ortaya konulacaktır.

\subsection{Elde Edilen Bulgular ve Yorumlanması}

Unilever ve P\&G markalarına ait ürünlerin Cosmopolitan Türkiye dergisinin Nisan 2015- Nisan 2016 tarihleri arasında yayınlanan toplam 12 sayıda yer alan reklamlar, sözel retorik betileri niceliksel ve

\footnotetext{
${ }^{1}$ Unilever Türkiye pazarında kişisel bakım ürünleri başta olmak üzere, ev bakımı gıda ve dondurma kategorisinde ürünleri bulunmaktadır. $P \& G$ ise, aile bakım ürünleri, güzellik ve kişisel bakım ürünleri kategorisinde ürünler ile tüketicilere hizmet etmektedir.
} 
niteliksel içerik analizi yöntemi ile bulgulanmaya çalışılmıştır. Ayrıca görsel betilerin ortaya konması amacı ile reklamlar göstergebilimsel analiz yöntemine tabi tutulmuştur.

3.3.1. Unilever ve P\&G Markalarına Ait Ürünlerin Cosmopolitan Türkiye Dergisinde Yer Alan Reklamlarının Retorik Yapılarının ve Retorik Figürlerin Niceliksel İçerik Analizi

Tablo 2. Yayınlanan Reklam Sayısı

\begin{tabular}{|l|c|c|}
\hline Tarih & İlan Sayısı & Yüzdelik \\
\hline 2015 & 16 & $\% 73$ \\
\hline 2016 & 6 & $\% 27$ \\
\hline Toplam & $\mathbf{2 2}$ & $\mathbf{\% 1 0 0}$ \\
\hline
\end{tabular}

Unılever ve P\&G markalarına ait ürünlerin Nisan 2015- Nisan 2016 tarihleri arasında yayınlanan 12 Cosmopolitan Türkiye dergisinde yer alan, araştırmaya dahil edilen tam sayfa ilan sayısı 22'dir. Bu ilanların 16 adedini 2015 yılına ait ilanlar oluşturmaktadır. 2016 yılında ise yayınlanan 6 ilan incelenmiştir.

Tablo 3. Retorik Tür Analizleri

\begin{tabular}{|c|c|c|}
\hline \multicolumn{3}{|c|}{ RETORİK YAPI } \\
\hline Retorik Türleri & N & Yüzdelik \\
\hline Politik Retorik & 5 & $\% 23$ \\
\hline Adli Retorik & 2 & $\% 9$ \\
\hline Epideiktik Retorik & 15 & $\% 68$ \\
\hline Retorik Zaman & 3 & $\% 23$ \\
\hline Geçmiş & 6 & $\% 65$ \\
\hline Gelecek & 17 & $\% 5$ \\
\hline Şimdi & 11 & $\% 45$ \\
\hline Retorik Amaçlar & 1 & $\% 100$ \\
\hline Tanitmak & 10 & \\
\hline Saptamak & 22 & \\
\hline Kanitlamak & 112 & \\
\hline & & \\
\hline
\end{tabular}

Tablo 3'de incelenen ilanların retorik yapısının niceliksel verileri görülmektedir. Retorik tür bağlamında, reklamlarda sık kullanılan epideiktik (Törensel) söylev en çok kullanılan tür olmuştur. Reklamlarda kullanılan ikinci retorik söylev ise, $\% 23$ oranıyla politik söylevdir. \%9 oranında da diğer bir tür olan adli söylevin varlığı gösterilmektedir. 
Tablo 4. Retorik Figür Kullanımları

\begin{tabular}{|l|l|l|}
\hline Retorik Figürler & N & Yüzdelik \\
\hline Şema (Biçimsel) Figürler & 14 & $\% 38$ \\
\hline Mecaz(Anlamsal) Figürler & 23 & $\% 67$ \\
\hline
\end{tabular}

Tablo 4'de incelenen ilanlarda kullanılan retorik figürlerin kullanım sayısı ve yüzdelikleri verilmiştir. Analiz edilen 22 kişisel bakım ilanında, toplam 37 retorik figür kullanılmıştır. Anlamsal figürler \%67 oranında kullanılırken, biçimsel figürler $\% 38$ oranında kullanılmıştır.

\subsubsection{Unılever ve P\&G Markalarına Ait Ürünlerin Cosmopolitan Türkiye Dergisinde Yer Alan Reklamlarının Retorik Yapı ve Retorik Figürlerinin Niteliksel İçerik Analizi}

Tablo 5. Üç İkna Kanıtı Analizleri, Ethos (Kaynağın Niteliği)

\begin{tabular}{|l|l|}
\hline \multicolumn{2}{|l|}{ Ethos (Kaynağın Niteliği) } \\
\hline Uzman & $\% 15$ \\
\hline Güvenilir & $\% 56$ \\
\hline Çekici & $\% 29$ \\
\hline
\end{tabular}

Kaynağın niteliğine ilişkin analizlerde, kişisel bakım ürünü reklamlarında güvenilirliğe ilişkin çağrışımların en fazla kullanıldığı görülmektedir. Kaynağın niteliğine ilişkin, fiziksel çekicilik \%29 ile ikinci sırada iken, uzmanlık olarak sıralanan niteliğin \%15 ile en az oranda kullanıldığı görülmektedir.

Tablo 6. Üç İkna Kanıtı Analizleri, Pathos (Duygusal Çekicilikler)

\begin{tabular}{|l|l|}
\hline \multicolumn{2}{|l|}{ Pathos (Duygusal Çekicilikler) } \\
\hline Güven & $\% 45$ \\
\hline Heyecan & $\% 33$ \\
\hline Sakinlik & $\% 7$ \\
\hline Korku & $\% 12$ \\
\hline Cinsellik & $\% 2$ \\
\hline Mizah & $\% 0$ \\
\hline Kıskanma & $\% 0$ \\
\hline Aşk & $\% 0$ \\
\hline Eğlence & $\% 0$ \\
\hline
\end{tabular}

Kişisel bakım ürünü reklamlarında en fazla kullanılan duygusal yaklaşım "güven” olurken, heyecan duygusu ikinci sırada, korku ise üçüncü sırada gelmektedir. Diğer kullanılan duygusal çekicilikler \%7 ile sakinlik, \%2 ile cinsellik olarak görülmektedir. Mizah, kıskanma, aşk ve eğlence duygularına kişisel bakım ürünü reklamlarında rastlanmamıştır. 
Tablo 7. Üç İkna Kanıtı Analizleri, Logos (Mantıksal Kanıtlar)

\begin{tabular}{|l|l|}
\hline \multicolumn{2}{|l|}{ Logos (Mantıksal Kanıtlar) } \\
\hline İstatistik & $\% 27$ \\
\hline Anlatılar & $\% 5$ \\
\hline Tanıklık & $\% 16$ \\
\hline Görsel Kanıt & $\% 14$ \\
\hline Karşılaştırma & $\% 20$ \\
\hline Bilgi Verme & $\% 18$ \\
\hline
\end{tabular}

Kişisel bakım ürünü reklamlarında en çok kullanılan mantıksal kanıt istatistik olduğu görülmektedir. Bir sonraki mantıksal kanıt ise, karşılaştırmadır. Tanıklık, görsel kanıt, karşılaştırma ve bilgi verme mantıksal kanıtları kullanım oranları birbirlerine oldukça yakındır. En az kullanılan kanıt, \%5 oranı ile anlatılardır.

Tablo 8. Retorik Figür Kullanımı

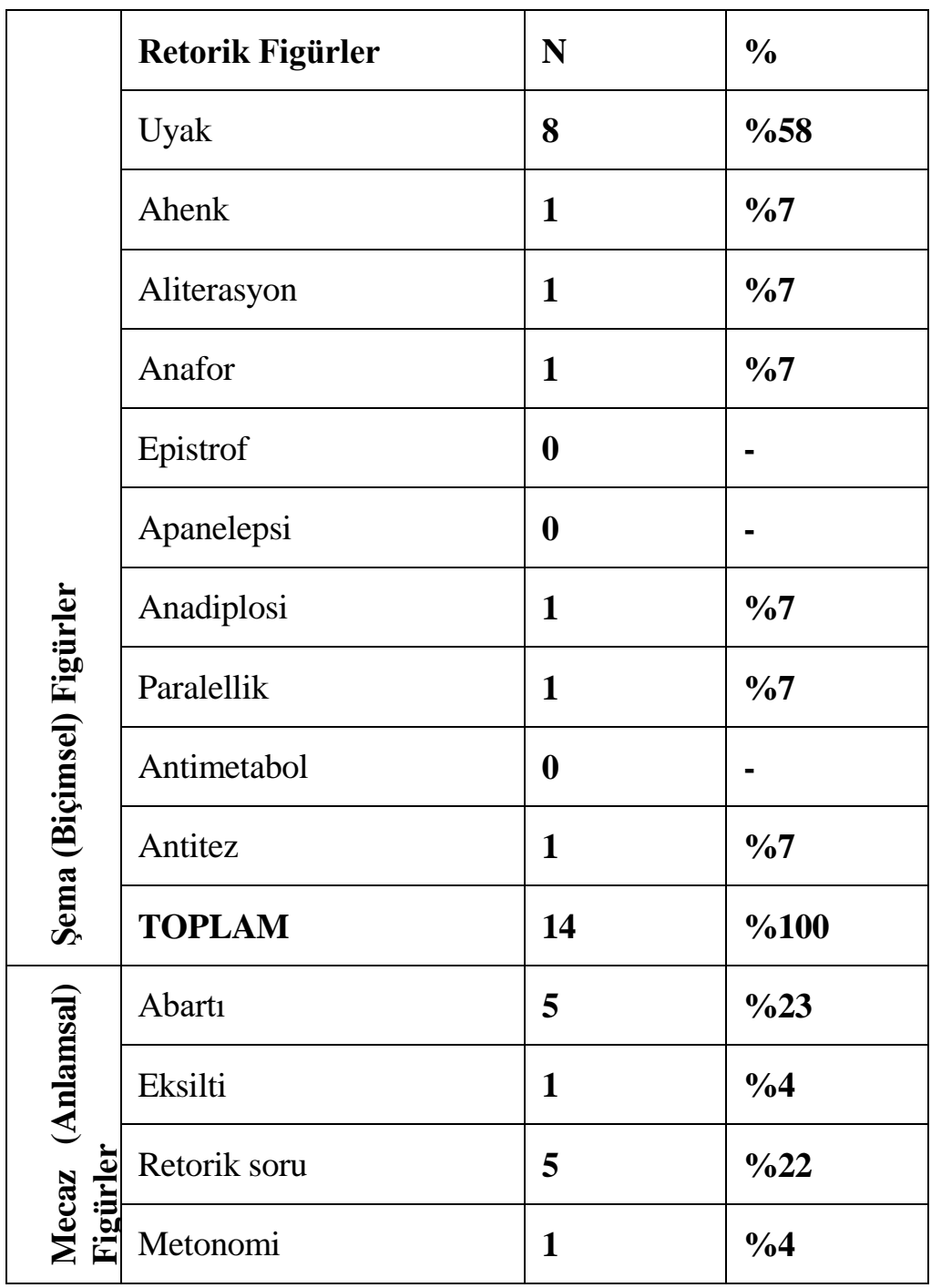




\begin{tabular}{|l|l|l|l|}
\hline (Düzdeğişmece) & & \\
\hline Eğretileme & $\mathbf{1}$ & $\mathbf{\% 4}$ \\
\hline Cinas & $\mathbf{1}$ & $\mathbf{\% 4}$ \\
\hline Paradoks & $\mathbf{3}$ & $\mathbf{\% 1 3}$ \\
\hline İroni & $\mathbf{0}$ & - \\
\hline Kişileştirme & $\mathbf{6}$ & $\mathbf{\% 2 6}$ \\
\hline TOPLAM & $\mathbf{2 3}$ & $\mathbf{\% 1 0 0}$ \\
\hline
\end{tabular}

Retorik figürlerin kullanımına yönelik oluşturulan tabloda, 22 ilanda toplam 37 adet retorik figürün kullanıldığı gözlenmiştir. Şematik (biçimsel) figürlerin kullanımına bakıldığında uyak figürünün büyük bir farkla en fazla kullanılan biçimsel figür olduğu görülmektedir. Daha sonra aynı oranlarda (\%7) ahenk, aliterasyon, anafor, anadiplosi ve paralellik figürleri takip etmektedir.

Mecaz (anlamsal) figürlerin, kullanım oranlarına bakıldığında, reklamcılıkta en fazla kullanılan figürlerden biri olan kişileştirme figürü (\%26) en fazla kullanılan figür olarak görülmektedir. Abartı ve retorik soru figürlerinin kullanım oranları da birbirlerine oldukça yakındır. Kişisel bakım ürünü reklamlarında figüratif dil kullanımının en önemli örneklerinden olan düzdeğişmece (yeniden adlandırma) ve eğretileme (benzetme) kullanımları (\%4) oldukça düşük olduğu gözlemlenmiştir.

\subsubsection{Unılever ve P\&G Markalarına Ait Ürünlerin Cosmopolitan Türkiye Dergisinde Yer Alan Reklamlarının Göstergebilimsel Analizi}

Tablo 9. Reklamların Göstergebilimsel Analizi

\begin{tabular}{|c|c|c|c|c|}
\hline Reklam & Anlama İşlevi & Görsel Yapı & Estetik Yapı & Aralarında Bağlantı Kurulan Durum \\
\hline 1. $\mathrm{P} \& \mathrm{G} /$ Oral B & $\begin{array}{l}\text { Bağlant1 } \\
\text { Kurma }\end{array}$ & Yan yana Koyma & Görme & $\begin{array}{l}\text { Görsel de Oral B markası ve "1 numaralı marka" } \\
\text { yazısı yan yana verilerek aralarında bağlantı } \\
\text { kurulması hedeflenmiş̧tir. }\end{array}$ \\
\hline $\begin{array}{lr}\text { 2. P\&G } & \text { /Pantene } \\
\text { Saç } & \text { Fırçanızla } \\
\text { Barışın } & \end{array}$ & $\begin{array}{l}\text { Bağlant1 } \\
\text { Kurma } \\
\text { /Birleştirme }\end{array}$ & $\begin{array}{l}\text { Yan yana Koyma / } \\
\text { Birleştirme }\end{array}$ & Görme & $\begin{array}{l}\text { Görselde saç teli bulunmayan saç firçası ve sağliklı } \\
\text { saçlar aralarında bağlantı kurulması hedeflenerek } \\
\text { saçlar yan yana verilmiştir. } \\
\text { Pantene Şampuan ve Pro-V vitamini görseli } \\
\text { birleştirilmiş şekilde verilmiştir. Şampuanın } \\
\text { içerisinde Pro-V vitamini olduğu vurgulanmak } \\
\text { istenmiştir. }\end{array}$ \\
\hline $\begin{array}{l}\text { 3. P\&G / Wella } \\
\text { Koleston/Artık Bir } \\
\text { Şeylerin Değişme } \\
\text { Zamanı Gelmişti }\end{array}$ & $\begin{array}{l}\text { Bağlantı } \\
\text { Kurma }\end{array}$ & Yerine Koyma & Görme & $\begin{array}{l}\text { Özge Özpirinçci, metafor olarak Wella Koleston } \\
\text { saç boyası ürünü yerine görselde yer almıştır. } \\
\text { Görsel Eğretileme kullanılmıştır. }\end{array}$ \\
\hline $\begin{array}{l}\text { 4. P\&G / İpana } 3 \\
\text { Boyutlu Beyazlik }\end{array}$ & $\begin{array}{l}\text { Benzerlik } \\
\text { Yaratma }\end{array}$ & Yan yana Koyma & Görme & $\begin{array}{l}\text { Shakira'nın dişleri ile ipana diş macunu yan yana } \\
\text { konularak, Shakira'nın 1şıldayan beyaz dişleri ile } \\
\text { diş macunu arasında bağlantı kurulmas1 } \\
\text { hedeflenmiştir. }\end{array}$ \\
\hline $\begin{array}{l}\text { 5. P\&G / Pantene } \\
/ \text { Bu Yaz da } \\
\text { Saçlarınız Koruma } \\
\text { Altında }\end{array}$ & $\begin{array}{l}\text { Bağlant1 } \\
\text { Kurma }\end{array}$ & Birleştirme & Görme & $\begin{array}{l}\text { Görselde, Argan yağlı saç bakım yağı- Argan } \\
\text { bitkisi ile birleştirilerek verilmiştir. Aralarında } \\
\text { bağlantı kurulması istenen durum, saç bakım } \\
\text { yağının argan yağı içerdiğidir. } \\
\text { Saç bakım yağları beyaz kum içinde verilmiştir. Saç }\end{array}$ \\
\hline
\end{tabular}




\begin{tabular}{|c|c|c|c|c|}
\hline & & & & $\begin{array}{l}\text { bakım yağının yaz mevsimi ile bağlantı kurulması } \\
\text { hedeflenmiştir. }\end{array}$ \\
\hline $\begin{array}{l}\text { 6. P\&G /Pantene } \\
\text { /Yaz Yaklaşırken }\end{array}$ & $\begin{array}{l}\text { Bağlant1 } \\
\text { Kurma }\end{array}$ & $\begin{array}{l}\text { Yan yana Koyma } \\
\text { /Birleştirme }\end{array}$ & Görme & $\begin{array}{l}\text { Şampuan, saç kremi ve bakım yağı- bikini, kolye, } \\
\text { parmak arası terlik ile yan yana verilmiştir. Yaz } \\
\text { mevsimi vurgusu yapılarak saç kreminin önemi } \\
\text { hedeflenmiştir. Görselde abartı (Hyperbole) } \\
\text { kullanılmıştır. } \\
\text { Bergüzar Korel ve Pro-V vitamini görseli } \\
\text { birleştirilerek verilmiştir. Bağlantı kurulması } \\
\text { istenen durum, Bergüzar Korel'in saçları ile Pro-V } \\
\text { vitaminidir. }\end{array}$ \\
\hline $\begin{array}{l}\text { 7. Unilever / } \\
\text { Vaseline Sprey }\end{array}$ & $\begin{array}{l}\text { Benzerlik } \\
\text { Kurma }\end{array}$ & Yerine Koyma & Görme & $\begin{array}{l}\text { Vaseline el kremi yerine çiçek şeklinde İpek bir } \\
\text { kumaşa yer verilmiştir. Görsel Eğretileme } \\
\text { kullanılmıştır. }\end{array}$ \\
\hline $\begin{array}{l}\text { 8. Unilever / Venüs } \\
\text { /Breeze }\end{array}$ & $\begin{array}{l}\text { Benzerlik } \\
\text { Kurma }\end{array}$ & Birleştirme & Görme & $\begin{array}{l}\text { Venüs tıraş bıçağ ç̧içek zeminin de birleştirilerek } \\
\text { verilmiştir. Yumuşaklık ve güzellik benzerliği } \\
\text { kurulması hedeflenmiştir. Görsel Eğretileme } \\
\text { kullanılmıştır. }\end{array}$ \\
\hline $\begin{array}{l}\text { 9. P\&G / Pantene } \\
\text { /Şekillendirmeye } \\
\text { Evet Yıpranmaya } \\
\text { Hayır }\end{array}$ & $\begin{array}{l}\text { Bağlant1 } \\
\text { Kurma }\end{array}$ & $\begin{array}{l}\text { Yan yana Koyma } \\
\text { /Birleştirme }\end{array}$ & Görme & $\begin{array}{l}\text { Bergüzar Korel'in şekillendirilmiş ve sağlıklı } \\
\text { saçları şampuanlarla yan yana verilmiştir. Bağlantı } \\
\text { kurulması istenen durum, Bergüzar Korel'in } \\
\text { saçları ve Pantene'dir. } \\
\text { Şampuanlar PRO-V vitamini görseli ile } \\
\text { birleştirilerek verilmiştir. Şampuanların içinde } \\
\text { PRO-V vitamini olduğu vurgulanmak istenmiştir. }\end{array}$ \\
\hline $\begin{array}{l}\text { 10. P\&G/ Pantene } \\
\text { /Her Y1kamada } \\
\text { Daha Sağlıklı }\end{array}$ & $\begin{array}{l}\text { Bağlantı } \\
\text { Kurma } \\
\text { /Benzerlik } \\
\text { Yaratma }\end{array}$ & $\begin{array}{l}\text { Yan yana Koyma/ } \\
\text { Birleştirme }\end{array}$ & Görme & $\begin{array}{l}\text { Bergüzar Korel'in saçları şampuanlar ile yan yana } \\
\text { verilmiştir. Bağlantı kurulması istenen durum, } \\
\text { Bergüzar Korel'in saçları ve Pantene'dir. } \\
\text { Panten şampuanlar PRO-V formülü görseli ile } \\
\text { birleştirilerek verilmiştir. Şampuanların içinde } \\
\text { PRO-V vitamini olduğu vurgulanmak istenmiştir. }\end{array}$ \\
\hline $\begin{array}{l}\text { 11. Unilever / } \\
\text { Elidor/ Bu Sevgi } \\
\text { Devam Ediyor }\end{array}$ & $\begin{array}{l}\text { Bağlantı } \\
\text { Kurma } \\
\text { /Benzerlik } \\
\text { Yaratma }\end{array}$ & $\begin{array}{l}\text { Yan yana koyma/ } \\
\text { Birleştirme }\end{array}$ & Görme & $\begin{array}{l}\text { Meryem Uzerli ile } 5 \text { rakamı yan yana konularak } \\
\text { aralarında benzerlik oluşturulmuştur. Meryem } \\
\text { Uzerli’nin } 5 \text { yıldır Türkiye'de olması ve sevilmesi } \\
\text { ile Elidor arasında bağlantıs kurulmas } \\
\text { hedeflenmiştir. } 5 \text { rakamı ile kalp sembolü } \\
\text { birleştirilmiştir. Görsel Synecdoche kullanılmıştır. }\end{array}$ \\
\hline $\begin{array}{l}\text { 12. Unilever / } \\
\text { Dove /Saç Kırıkları }\end{array}$ & Karşılaştırma & Yan yana koyma & Görme & $\begin{array}{l}\text { Görselde saç kırıklarını öncesi ve sonrası ile yan } \\
\text { yana verilmiş, karşılaştırma yapılmıştır. }\end{array}$ \\
\hline $\begin{array}{l}\text { 13. Unilever / } \\
\text { Elidor/Canlandırıcı } \\
\text { Kuru Şampuan }\end{array}$ & Karşılaştırma & Yan yana koyma & Görme & $\begin{array}{l}\text { Üç farklı Elidor kuru şampuan bir stand üzerinde } \\
\text { yan yana verilmiştir. Karşılaştırma yapılması } \\
\text { içlerinden birinin seçilmesi hedeflenmiştir. }\end{array}$ \\
\hline $\begin{array}{l}\text { 14. P\&G / Pantene } \\
\text { /Argan Yağlı }\end{array}$ & $\begin{array}{l}\text { Bağlant1 } \\
\text { Kurma }\end{array}$ & Birleştirme & Görme & $\begin{array}{l}\text { Argan yağı ile saç bakım yağı birleştirilerek } \\
\text { verilmiştir. Saç bakım yağının argan yağı içerdiği } \\
\text { bağlantı kurulması istenmiştir. }\end{array}$ \\
\hline $\begin{array}{l}\text { 15. P\&G / } \\
\text { Head\&Shoulders }\end{array}$ & $\begin{array}{l}\text { Benzerlik } \\
\text { Yaratma }\end{array}$ & Yan yana koyma & Görme & $\begin{array}{l}\text { Head\&Shoulders şampuan görseldeki mankenin } \\
\text { kepeksiz ve güzel saçları ile yan yana konulmuştur. } \\
\text { Bakımlı saçlar ile Head\&Shoulders şampuan } \\
\text { arasında bağlantı kurulması hedeflenmiştir. }\end{array}$ \\
\hline
\end{tabular}


Tüketim Kültürü ve İkna Bağlaminda Reklamda Retorik Figürlerin Kullanimi Üzerine Bir İnceleme

\begin{tabular}{|c|c|c|c|c|}
\hline $\begin{array}{l}\text { 16. P\&G/ Pantene } \\
\text { /Saç Dökülmesi }\end{array}$ & $\begin{array}{l}\text { Bağlant1 } \\
\text { Kurma }\end{array}$ & Yan yana koyma & Görme & $\begin{array}{l}\text { Bergüzer Korel'in sağlıklı saçları ve üzerinde saç } \\
\text { teli olmayan saç firçası yan yana konulmuştur. } \\
\text { Bağlantı kurulması istenen durum, Pantene } \\
\text { kullanan Bergüzar Korel ile saç firçası arasındaki } \\
\text { ilişkidir. }\end{array}$ \\
\hline $\begin{array}{l}\text { 17. P\&G/ Pantene } \\
/ 15 \text { kat daha güçlü }\end{array}$ & $\begin{array}{l}\text { Benzerlik } \\
\text { Yaratma }\end{array}$ & Yan yana koyma & Görme & $\begin{array}{l}\text { Yeni formüllü saç şampuanı Pantene, bakım yağı ve } \\
\text { kremi; mankenin güçlü ve sağlıklı saçları ile yan } \\
\text { yana verilmiştir. Aralarında bağlantı kurulmas } \\
\text { hedeflenmiştir. }\end{array}$ \\
\hline $\begin{array}{l}\text { 18. Unilever/ } \\
\text { Jillette Venüs }\end{array}$ & $\begin{array}{l}\text { Benzerlik } \\
\text { Yaratma }\end{array}$ & Yan yana koyma & Görme & $\begin{array}{l}\text { Prüzsüz güzel bir kadın bacağı ve Venüs Jilet yan } \\
\text { yana verilmiştir. Aralarında bağlantı kurulması } \\
\text { hedeflenmiştir. }\end{array}$ \\
\hline 19. $\mathrm{P} \& \mathrm{G} /$ Orkid & $\begin{array}{l}\text { Benzerlik } \\
\text { Yaratma }\end{array}$ & Birleştirme & Görme & $\begin{array}{l}\text { Orkid ürünü, pamukların içerisinde birleştirilerek } \\
\text { verilmiştir. Görsel Eğretileme kullanılmıştır. }\end{array}$ \\
\hline 20. $P \& G /$ Braun & $\begin{array}{l}\text { Bağlant1 } \\
\text { Kurma }\end{array}$ & Yerine Koyma & Görme & $\begin{array}{l}\text { Anne-kız fotoğrafi hediye paketi şekilde verilmiştir. } \\
\text { Görselde Ellipsis figürü kullanılmıştır. }\end{array}$ \\
\hline $\begin{array}{l}\text { 21. P\&G/ Head \& } \\
\text { Shoulders /Size } \\
\text { uygun hangisi? }\end{array}$ & $\begin{array}{l}\text { Bağlant1 } \\
\text { Kurma }\end{array}$ & Yanyana koyma & Görme & $\begin{array}{l}\text { Head \& Shoulders şampuan, Sofia Vergara'nın } \\
\text { saçları ile yan yana verilmiştir. Aralarında bağlantı } \\
\text { kurulması hedeflenmiştir. }\end{array}$ \\
\hline 22. P\&G/ İpana & $\begin{array}{l}\text { Bağlantı } \\
\text { Kurma } \\
\text { /Benzerlik } \\
\text { Yaratma }\end{array}$ & Yanyana koyma & Görme & $\begin{array}{l}\text { Ürün ve Diş Doktoru yan yana verilmiştir. Uzman } \\
\text { görüşü alındığı gösterilmek istenmiştir. İpana diş } \\
\text { macunu ile Ezgi Mola'nın dişleri yan yana verilmiş, } \\
\text { aralarında bağlantı kurulması istenmiştir. }\end{array}$ \\
\hline
\end{tabular}

İncelenen 22 kişisel bakım ürünü reklamında anlama işlevi benzerlik yaratma, bağlantı kurma veya karşılaștırma șeklinde gerçekleşmiştir. Görsel yapı genel olarak, yan yana koyma ve birleștirme biçiminde kullanılırken, yerine koyma işlevinin, görsel retorik figürlerin kullanıldı̆̆ 1 , P\&G / Wella Koleston/Artık Bir Şeylerin Değişme Zamanı Gelmişti, P\&G/ Braun ve Unilever / Vaseline Sprey reklamlarında kullanıldığı görülmektedir. Estetik Yapı, kişisel bakım ürünü reklamları olması sebebiyle tüm reklamlarda görme olarak kullanılmıştır. Aralarında bağlantı kurulan durum retorik figürler açısından bakıldığında, P\&G / Wella Koleston/Artık Bir Şeylerin Değişme Zamanı Gelmişti, adlı reklamda, görsel eğritileme kullanılmıştır. Reklamda Özge Özpirinçci, metafor olarak Wella Koleston saç boyası ürünü yerine görselde değişimi temsil ederek yer almıştır. P\&G /Pantene /Yaz Yaklaşırken adlı reklamda, Saç bakım yağlarının yazın vazgeçilmezi şeklinde gösterilmesi, reklamda abartı (Hyperbole) kullanıldığının göstergesidir. Bir diğer reklam Unilever/Bu Sevgi Devam Ediyor adlı reklamdır. Reklamda 5 rakamı ile kalp sembolü birleştirilmiştir. Görsel Synecdoche kullanılmıştır. P\&G / Orkid reklamında Orkid ürünü, pamukların içerisinde birleştirilerek verilmiştir. Görsel Eğretileme kullanılmıştır P\&G/ Braun ürünü reklamında ise, anne-kız fotoğrafi hediye paketi şekilde verilmiştir, görsel farklı anlamlar içermektedir. Ellipsis figürü kullanıldığı düşünülmektedir.

\section{Sonuç ve Değerlendirme}

Bu çalışmada, okur kitlesini tüketici kitleye dönüştürmek adına yazılı basının bir parçası olan dergiler de yer alan reklamların retoriği anlaşılmaya çalışılmıştır. Reklamlar ile gerçek gereksinimlerin dışında yapay gereksinimlerin dayatıldığı ve bireylerin bu gereksinimleri gerçekmiş gibi görmelerini ve tüketimini ikna etmek adına retoriğin gücünden yararlanıldığı düşüncesinden hareketle, Türkiye'de 2015 yılında yazılı basında en fazla reklam veren Unilever ve P\&G markalarına ait ürünlerin, 2015 yılı Kadın ve Moda dergisi kategorisinde en eski ve fazla tiraja sahip olan dergilerden biri olan Cosmopolitan Türkiye dergisinde Nisan 2015- Nisan 2016 tarihleri arasında yayınlanan toplam 12 sayıda yer alan reklamları dilsel ve görsel retorik betiler kapsamında analiz edilmiştir. Elde edilen bulgular tasarlanan araştırma soruları çerçevesinde aşağıdaki şekilde yorumlanmıştır. 
Kişisel bakım ürünleri reklamlarında en çok kullanılan retorik türü, reklamlarda sıklıkla kullanılan \% 68 oranla epideiktik (Törensel) söylevdir. Reklamlarda kullanılan ikinci retorik söylev ise,\%23 oranıyla politik söylevdir, $\% 9$ oranında da diğer bir tür olan adli söylevin kullanıldığı görülmüştür. Türe göre zaman kullanımının en orantılı olduğu bölüm, politik söylevin kullandığı gelecek zamanda (\%23) görülmektedir. Bazı ilanlarda epideiktik söylev türünün şimdiki zamanla birlikte, geçmiş zamanında kullanılması epideiktik söylevin kapsayıcılığına işaret etmektedir.

Retorik söylevler tanıtmak, kanıtlamak ve saptamak amacına hizmet etmektedir. Kişisel bakım ürünleri ilanlarında kullanılan dilin, amaçlarına ilişkin yapılan analizde tanıtmak amacının kullanım sıklığı dikkat çekmektedir. Barokas'a göre (2011, s. 97), bir düşünce ya da bir olgunun tanıtımı politik konuşmalarla yapılmaktadır. Ancak reklamlarda en çok kullanılan tanıtma amacının politik söylevden bağımsız olarak kullanıldığı analizlerden anlaşılmaktadır.

Kaynağın niteliğine ilişkin analizlerde, kişisel bakım ürünü reklamlarında güvenilirliğe ilişkin çağrışımların en fazla kullanıldığ 1 görülmektedir. Kişisel bakım ürünü gibi hassasiyeti yüksek olan tüketim ürünleri kategorisinde, hedef kitleye ürüne olan güven duygusu kazandırılmak istendiği anlaşılmaktadır. Kaynağın niteliğine ilişkin, fiziksel çekicilik \%29 ile ikinci sırada iken, uzmanlık olarak sıralanan niteliğin \%15 ile en az oranda kullanıldığı görülmektedir.

Kişisel bakım ürünü reklamlarında en fazla kullanılan duygusal yaklaşım "güven" olurken, heyecan duygusu ikinci sırada, korku ise üçüncü sırada gelmektedir. Diğer kullanılan duygusal çekicilikler \%7 ile sakinlik, \%2 ile cinsellik olarak görülmektedir. Mizah, kıskanma, aşk ve eğlence duygularına kişisel bakım ürünü reklamlarında rastlanmamıştır.

Kişisel bakım ürünleri; temizlik, sağlı, beslenme gibi ihtiyaçlarımızı karşılarken aynı zamanda özellikle kadınlarda, fark edilme ve dikkat çekme amacıyla makyaj, cilt bakımı, güzel ve dikkat çeken ürünler giyerek daha üste seviyelerde olma sosyal ve saygınlık ihtiyaçlarını tatmin gibi amaçları da gerçekleştirmektir. Bu bakımdan tüketiciler, kişisel bakım ürünü tercih ederken en çok güven duygusuna ihtiyaç duyarlar.

Reklamlar içindeki metinlerle, hedef kitleye verilen mesajı detaylandırma ya da etkisini artırmak için kullanılan mantıksal kanıtlar 6 kategoride toplanmıştır. Kişisel bakım ürünü reklamlarında en çok kullanılan mantıksal kanıt istatistik olduğu görülmektedir. Reklamlarda sayısal veriler kullanılarak, tüketicinin güvenini kazanmak amaçlanmaktadır. Güveni kazanılan tüketiciyi ikna etmek daha kolaydır. İncelenen reklamlarda tanıklık, görsel kanıt, karşılaştırma ve bilgi verme mantıksal kanıtları kullanım oranları birbirlerine oldukça yakındır. En az kullanılan kanıt, \%5 oranı ile anlatılardır. Burada tüketicinin kişisel bakım ürünü tercih ederken başkalarının kullanım tecrübelerinin çok önemsenmediği düşünülmüştür.

Retorik figürlerin kullanımına yönelik gerçekleştirilen incelemede 22 ilanda toplam 37 adet retorik figürün kullanıldığı gözlenmiştir. Şematik (biçimsel) figürlerin kullanımına bakıldığında, Seslerin tekrarı neticesinde ortaya çıkan uyak figürünün en fazla kullanılan biçimsel figür olduğu görülmektedir. Daha sonra aynı oranlarda (\%7) ahenk, aliterasyon, anafor, anadiplosi ve paralellik figürleri takip etmektedir.

Mecaz (anlamsal) figürlerin, kullanım oranlarına bakıldığında, reklamcılıkta en fazla kullanılan figürlerden biri olan kişileştirme figürünün (\%26) en fazla kullanılan figür olduğu görülmektedir. Reklam metinlerinin tüketici zihninde hatırlanma süreci önemlidir. Mecaz figürler alt anlam oluşturacak şekilde kodlandıklarından, zihinsel süreçte yorumlanırken, metin ya da tümcelerin eksik bir anlam ifade ettikleri biçiminde algılanmaları dolayısıyla kullanımı bu noktada oldukça etkilidir. Tüketici zihninde daha fazla düşünmeye, daha fazla anlam çözümlemesine yol açarak zihinlerdeki marka ya da reklama ilişkin mevcut bağlantıları ve çağrışımları daha da güçlendirmektedir (Mitchell, 1983 aktaran McQuarrie ve Mick, 1996, 431 ).

Kişisel bakım ürünü reklamlarında anlama işlevi; benzerlik yaratma, bağlantı kurma veya karşılaştırma şeklinde gerçekleşmiştir. Görsel yap1 genel olarak, yan yana koyma ve birleştirme biçiminde kullanılırken, yerine koyma işlevinin kullanıldığı, P\&G / Wella Koleston/Artık Bir Şeylerin Değişme Zamanı Gelmişti, P\&G/ Braun ve Unilever / Vaseline Sprey reklamlarında görsel retorik figürlerin de 
kullanıldığı görülmektedir. Estetik Yapı, kişisel bakım ürünü reklamları olması sebebiyle tüm reklamlarda görme olarak ortaya çıkmaktadır.

Aralarında bağlantı kurulan durum retorik figürler açısından bakıldığında; P\&G / Wella Koleston/Artık Bir Şeylerin Değişme Zamanı Gelmişti, adlı reklamda, görsel eğritileme kullanılmıştır. Reklamda Özge Özpirinçci, metafor olarak Wella Koleston saç boyası ürünü yerine görselde değişimi temsil ederek yer almıştır. P\&G /Pantene /Yaz Yaklaşırken adlı reklamda, saç bakım yağlarının yazın vazgeçilmezi şeklinde gösterilmesi, reklamda abartı (Hyperbole) kullanıldığının göstergesidir. Unilever/Bu Sevgi Devam Ediyor adlı reklamdır. Reklamda 5 rakamı ile kalp sembolü birleştirilmiş̧ir. Görsel Synecdoche kullanılmıştır. P\&G / Orkid reklamında Orkid ürünü, pamukların içerisinde birleştirilerek verilmiştir. Görsel Eğretileme kullanılmıştır. P\&G/ Braun ürünü reklamında ise, anne-kız fotoğrafı hediye paketi şekilde verilmiştir, görsel farklı anlamlar içermektedir. Ellipsis figürü kullanıldığı düşünülmektedir.

Sonuç olarak çalışmanın varsayımlarını test etmek adına geliştirilen araştırma soruları verilerine dayanarak, reklamlarda retorik figürler kullanılarak yapay gereksinimlerin oluşturulduğunu söyleyebilir. Saç kremi, saç boyası, kuru şampuan, üç boyutlu diş firçası gibi temel ihtiyaç sayılamayacak olan ürünler, reklamlar ile tüketicilere edinilmesi gereken, önem arz eden gereksinimler olarak sunulmaktadır. Ve bu sunumlarda reklamcılar tüketiciyi ikna etmek adına retorik disiplininden yararlanmaktadır. Reklam mesajlarında sözel ve görsel retorik figürlerin kullanıldı̆̆ saptanmıştır. Konu ile ilgili gelecekte yapılacak çalışmaların farklı kategorilerdeki ürünler veya farklı mecralardaki reklamlar üzerine yapılması reklamda retoriksel figürlerin kullanımı adına alan yazında bütünlük sağlayacağı düşünülmektedir.

Bilgilendirme / Acknowledgement: Bu Çalışma 1. Uluslararası Bilimsel Araştırmalar Kongresi-İnan ve Toplum Bilimleri (IBAD-2016) Madrid, İSPANYA'da sözlü bildiri olarak sunulmuştur.

\section{KAYNAKÇA}

Altınörs, A. (2011). Platon ile Aristotales'in retorik anlayışlarının karşılaştııılması. Ekev Akademi Dergisi, 15, 49.

Akçalı, İ.S. (2006). Günlük yaşamda reklam ve büyülenmiş tüketiciler. S. İ. Akçalı (Ed.) Gündelik Hayat ve Medya. içinde, s. 97-114. Ankara: Ebabil Yayınları

Akerson, F.E. (2005). Göstergebilime giriş. İstanbul: Multilingual

Aristoteles. (2013). Retorik. (M. Doğan, Çev.) İstanbul: Yapı Kredi Yayınları

Argın Ş. (1998). Tüketicinin üretimi ve benlik promosyonu. Birikim Dergisi, 110, 87-95.

Aydoğan, F. (2005). Medya ve tüketim kültürü üzerine eleştirel bir analiz. İstanbul: Türkmen Kitabevi.

Aytaç, Ö. (2002). Boş zaman üzerine kuramsal yaklaşımlar. Firat Üniversitesi Sosyal Bilimler Dergisi, 12(1), 231-260.

Bal, H. (2016). Nitel araştırma yöntem ve teknikleri. İstanbul: Sentez Yayınları

Barthes, R. (1999). Göstergebilimsel serüven. (S. Rıfat, M. Rıfat, Çev.). İstanbul: Kaf Yayınları.

Barokas, S.K. (2011). Reklam ve retorik. İstanbul: Derin Yayınları

Baudrillard, J. (2015). Tüketim toplumu. (H. Deliceçaylı ve F. Keskin, Çev.). İstanbul: Ayrıntı Yayınları.

Bauman Z. (1999). Çalışma, tüketicilik ve yeni yoksullar, (Ü. Ökten Çev.). İstanbul : Sarmal Yayınevi

Barthes, R. (1977). Rhetoric of the image. New York: Hill and Wang.

Batı, U. (2007, Haziran). Reklamlarda retorik figürlerin kullanımı. Marmara Üniversitesi Sosyal Bilimler Enstitüsü Dergisi, 7(28), 327-335. 
Berger, J. (2002).Görme biçimleri. (Y. Salman, Çev.). İstanbul: Metis Yayınları.

Bıçakçı, İ. (2012). Sanayi toplumundan bilgi toplumuna tüketimin evrimi ve Türkiye' deki yansımaları. Uluslararası Insan Bilimleri Dergisi, 5(1), 1-25.

Bocock, R. (1997), Tüketim. (İ.Kutluk, Çev.). Ankara: Dost Kitabevi

Çam, M. S. (2015). Türkiye'de basın reklamlarının retoriği: Otohaber dergisinde 1992 ve 2012 yıllarında yayınlanan otomobil ilanlarının karşılaştırmalı içerik analizi. Yayınlanmamış yüksek lisans tezi, Ankara Üniversitesi Sosyal Bilimler Enstitüsü, Ankara.

Cutbirth, C.W. (2004). Classical rhetorical theory. Communication theories for everyday. Boston: Pearson

Corbett, E. (1990). Classical rhetoric for modern student. New York: Oxford University Press.

Coşku, A. (2011). İbn Sina felsefesinde retorik. İstanbul: Litera Yayınc1lı.

Dağtaş, B. (2009). Reklamlarl görmek, reklam metinlerinin ait olduğu kültürler ve egemen form olarak tüketim kültürü. (D. Telen, Ed.). İstanbul: Ütopya.

Davidson, Martin (1992). The consumerist manifesto:Advertising in postmodern times. Routledge:London, NewYork

Demirdöğen, Ü. (2010). The roots of research in (political) persuasion, ethos, pathos, logos and the yale studies of persuasive communications. International Journal of Social Inquiry, 1(3), 189-201.

Dilçin, C. (1995). Örneklerle türk şiir bilgisi. 3. Baskı. İstanbul: TDK Yayınları.

Dolu, Ş. (1993). Medya ve tüketim çılgınlı̆̆g. İstanbul: Düşünen Adam Yayınları.

Durand, J. (1987). Rhetorical figures in advertising image. marketing and semiotics, new directions in the study of sings for sale. New York: De Gruyter.

Douglas, M., Isherwood B. (1999). Tüketimin antropolojisi. (E. A. Aytekin Çev.) Ankara: Dost Kitabevi Yayınları.

Dyer, G. (2009). Advertising as communication. London and New York: Taylor \& Francis.

Fiske, J. (2014). İletişim çalışmalarına giriş. (S. İrvan, Çev.) Ankara: Pharmakon

Featherstone, M. (2005). Postmodernizm ve tüketim kültürü. (M. Küçük, Çev.) İstanbul: Ayrınt1 Yayınları.

Foss, K. S. (2005).Theory of visiul rhetoric.handbook of visual communication.theory, methods and media. New Jersey: Lawrence Erlbaum Associates.

Geçer, E. (2013). Medya ve popüler kültür, diziler, televizyon ve toplum. İstanbul: Metamorfoz Yayınları.

Gökçe, O. (2006). Içerik analizi. Ankara: Siyasal Kitabevi.

Güllüoğlu, Ö. (2012). İletişim bilimlerinde araştırma yöntemleri, görsel metin çözümleme. Ankara: Ütopya Yayınevi.

İnceoğlu, M. (2011). Tutum, algl, iletişim. Ankara: Siyasal Kitabevi.

Kast, B. (2011). European rhetoric. rhetorical analysis, presentation \& Public speaking 20 Temmuz 2019 tarihinde http//www.european-rhetoric.com/rhetoric-101/modes-persuasionaristotle/ethos/ adresinden erişildi.

Konyar, H. (2002). Türk magazin basınındaki 80 sonrası değişimler. İstanbul Üniversitesi İletişim Fakültesi Dergisi, 13, 181-196.

Lyon, D. (1994). Postmodernity. London: Open University.

Marcuse, H. (2010). Tek boyutlu insan. (A.Yardımlı Çev.). İstanbul: İdea Yayınevi. 
McQuarrie, E., Mick, D. (1996). Figures of rhetoric in advertising language. The Journal of Consumer Research, 22(4), 424-438.

McQuarrie, E., Phillips, B. (2005). Indirect persuasion in advertising - How consumers process metaphors presented in pictures and words. Journal of Advertising. 2(34), 7-20.

Meyer, M. (2009). Retorik. (İ. Yerguz, Çev.) Ankara: Dost Kitabevi Yayınları.

Odabaş1, Y. (2006). Tüketim kültürü. İstanbul: Sistem Yayıncılık

Özdemir, S. (1998) Medya emperyalizmi ve küreselleşme. İstanbul: Timaş Yayınları,

Rıfat, M. (2009). Göstegebilimin ABC'si. İstanbul: Say Yayınları

Rife, M. C. (2010). Ethos, pathos, logos, kairos, using a rhetorical heuristic to mediate digital-survey recruitment strategies. IEEE Transactions on Professional Communication, 3(53), 260-277.

Sandıkçığlu, B. (2014). İkna kuramları. İkna Edici İletişim içinde (M. Oyman, Ed.). 42-64, 64-88, 126152. Eskişehir: AÖF.

Saraç, M. A. Y. (2007). Klasik edebiyat bilgisi belagat. İstanbul : 3F Yayınları

Scott, L. (1994). Images in advertising, the need for a theory of visual rhetoric. Journal of Consumer Research, 2(21), 252-273.

Scott, L. M. (2008). Expanding rhetoric. In New directions in advertising rhetoric (E. McQuarrie, B. Phillips Ed.). 297-311. New York: Sharpe.

Sözen, E. (1999). Söylem, 'belirsizlik, mübadele, bilgi/güç ve refleksivite'. İstanbul: Paradigma Yay.

Sperber, D., Wilson, D. (1986). Relevance, communication and cognition. Cambridge: Harvard University Press.

Tamaşevski, B. (1995). Dize üstüne (içinde), Tzvetan Todorov, Yazım kuramı: "Rus biçimlerin metinleri”. (Mehmet Rifat, Sema Rifat, çev.). İstanbul: YKY

Torlak, Ö. (2000). Tüketim, bireysel eylemin toplumsal dönüşümü. İstanbul: İnkılap Yayınları.

Williamson, J.(2001). Reklamların dili. reklamlarda anlam ve ideoloji.(A. Fethi, Çev.) Ankara: Ütopya.

Yağlı, S. (2006). Gündelik hayatımızda akıl tutulması, medya uygulamalarında tüketim ideolojisinin izlerini sürmek. (S. İ. Akçalı, Ed.). Gündelik hayat ve medya. 5- 42. Ankara: Ebabil Yayınları.

Yengin, H. (1996). Medyanın dili. İstanbul: Der Yayınları.

Zıllığlu, M. ve Yüksel, A.H. (2005). İletişim bilgisi. Eskişehir: Anadolu Üniversitesi Yayınları. 